\title{
ULTRA-CLEAN DIESEL FUEL: U.S. PRODUCTION AND DISTRIBUTION CAPABILITY
}

\author{
G.R. Hadder \\ Center for Transportation Analysis \\ Oak Ridge National Laboratory \\ Oak Ridge, TN \\ B.D. McNutt \\ U.S. Department of Energy \\ Washington, DC
}

August 2000

Prepared for

Office of Energy Efficiency and Renewable Energy

U.S. Department of Energy

Prepared by the

OAK RIDGE NATIONAL LABORATORY

Oak Ridge, Tennessee 37831

managed by

UT-BATTELLE, LLC

for the

U.S. DEPARTMENT OF ENERGY

under contract DE-AC05-00OR22725 


\section{TABLE OF CONTENTS}

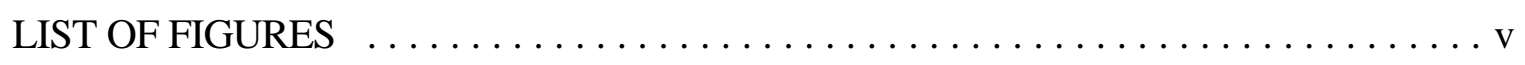

LIST OF TABLES $\ldots \ldots \ldots \ldots \ldots \ldots \ldots \ldots \ldots \ldots \ldots \ldots \ldots \ldots \ldots \ldots \ldots \ldots$

ACRONYMS AND ABBREVIATIONS $\ldots \ldots \ldots \ldots \ldots \ldots \ldots \ldots \ldots \ldots$ vii

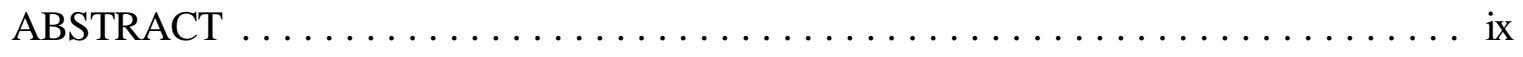

EXECUTIVE SUMMARY $\ldots \ldots \ldots \ldots \ldots \ldots \ldots \ldots \ldots \ldots \ldots \ldots \ldots \ldots \ldots \ldots \ldots \ldots$

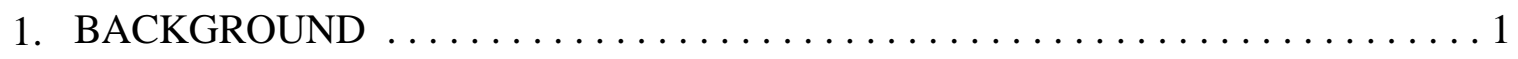

2. CURRENT DIESEL FUEL MARKET STRUCTURE $\ldots \ldots \ldots \ldots \ldots \ldots \ldots \ldots$

3. SMALL MARKET: LIGHT DUTY DIESEL FUEL $\ldots \ldots \ldots \ldots \ldots \ldots \ldots \ldots$

3.1 POTENTIAL LDDF SOURCES AND COST $\ldots \ldots \ldots \ldots \ldots \ldots \ldots \ldots$

3.2 POTENTIAL LDDF PRODUCTION $\ldots \ldots \ldots \ldots \ldots \ldots \ldots \ldots \ldots$

3.3 POSSIBLE REGULATORY REQUIREMENTS TO ASSURE

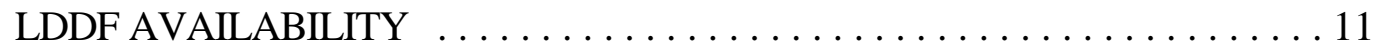

3.4 COST OF ASSURING RETAIL LDDF AVAILABILITY $\ldots \ldots \ldots \ldots \ldots 12$

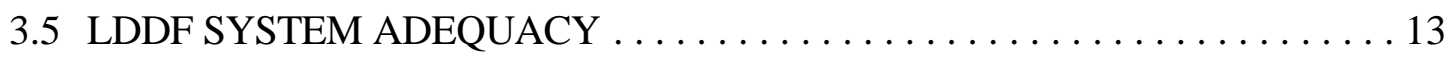

4. LARGE MARKET: REFORMULATED DIESEL FUEL $\ldots \ldots \ldots \ldots \ldots \ldots \ldots$

4.1 RECENT DIESEL FUEL PRODUCTION $\ldots \ldots \ldots \ldots \ldots \ldots \ldots \ldots \ldots \ldots \ldots$

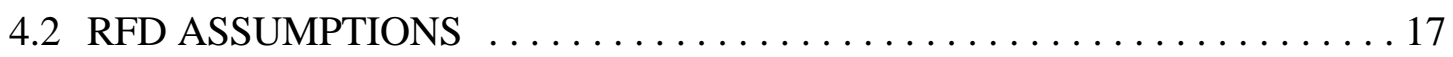

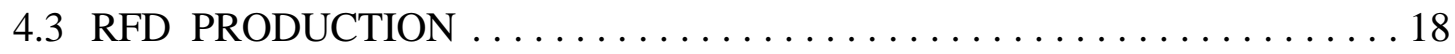

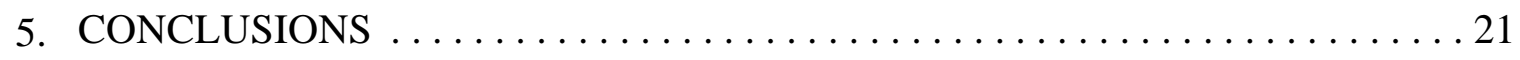

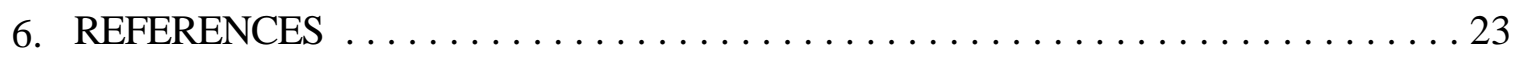




\section{LIST OF FIGURES}

Figure 1. U.S. Low Sulfur Diesel Blendstock Production $\ldots \ldots \ldots \ldots \ldots \ldots \ldots \ldots \ldots \ldots 9$

Figure 2. Low Sulfur Diesel Blendstock Production $\ldots \ldots \ldots \ldots \ldots \ldots \ldots \ldots \ldots \ldots$

Figure 3. Low Sulfur Diesel Blendstock Production in California . . . . . . . . . . . . . 10

\section{LIST OF TABLES}

Table 1. Diesel Fuel Blendstock Sulfur in $1996 \ldots \ldots \ldots \ldots \ldots \ldots \ldots \ldots$

Table 2. Refining Systems for Production of Low Sulfur Blendstocks for LDDF . . . . . . 10

Table 3. Diesel Fuel Production in 1997 for U.S. Excluding PADD V . . . . . . . . . . . 16

Table 4. U.S. Regional Production of Low Sulfur Diesel Fuel in 1997 . . . . . . . . . . . . 16

Table 5. Typical Blendstocks for Low Sulfur Diesel Fuel in PADD III . . . . . . . . . . 17

Table 6. Reformulated Diesel Fuel Assumed Requirements . . . . . . . . . . . . . . 18

Table 7. Blendstocks for Reformulated Diesel Fuel in PADD III . . . . . . . . . . . 19

Table 8. Refinery Process Investment Including Offsites . . . . . . . . . . . . . 20

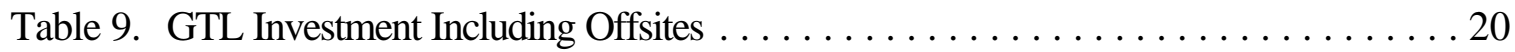





\title{
ACRONYMS AND ABBREVIATIONS
}

\author{
ANPRM Advance Notice of Proposed Rulemaking \\ API American Petroleum Institute \\ CRU Crude distillation \\ DOE U.S. Department of Energy \\ EPA U.S. Environmental Protection Agency \\ F Fahrenheit \\ FCC Fluid catalytic cracker \\ FDS Desulfurization of feed for fluid catalytic cracker \\ F-T Fischer-Tropsch \\ GTL Gas-to-liquids \\ HCR Hydrocracking \\ HDDV Heavy Duty Diesel Vehicle \\ HDS Hydrotreating \\ $\mathrm{H} 2 \quad$ Hydrogen production \\ LDDF Light duty diesel fuel \\ LDDV Light duty diesel vehicle \\ LDV Light duty vehicle \\ MB Thousand barrels \\ MBD Thousand barrels per day
}




$\begin{array}{ll}\text { Mmcfd } & \text { Million cubic feet per day } \\ \text { NOx } & \text { Oxides of nitrogen } \\ \text { NPRA } & \text { National Petrochemical and Refiners Association } \\ \text { NPRM } & \text { Notice of Proposed Rulemaking } \\ \text { PADD } & \text { Petroleum Administration for Defense District } \\ \text { PM } & \text { Particulate matter } \\ \text { ppm } & \text { Parts per million } \\ \text { RFD } & \text { Reformulated diesel fuel } \\ \text { T90 } & \text { The temperature at which } 90 \text { percent of a volume of fuel is } \\ & \text { evaporated in a standard test } \\ \text { vol } & \text { Volume }\end{array}$




\section{ABSTRACT}

Diesel engines have potential for use in a large number of future vehicles in the United States. However, to achieve this potential, proponents of diesel engine technologies must solve diesel's pollution problems, including objectionable levels of emissions of particulates and oxides of nitrogen. To meet emissions reduction goals, diesel fuel quality improvements could enable diesel engines with advanced aftertreatment systems to achieve the necessary emissions performance. The diesel fuel would most likely have to be reformulated to be as clean as low sulfur gasoline. This report examines the small- and large-market extremes for introduction of ultra-clean diesel fuel in the United States and concludes that petroleum refinery and distribution systems could produce adequate low sulfur blendstocks to satisfy small markets for low sulfur (30 parts per million) light duty diesel fuel, and deliver that fuel to retail consumers with only modest changes. Initially, there could be poor economic returns on under-utilized infrastructure investments. Subsequent growth in the diesel fuel market could be inconsistent with U.S. refinery configurations and economics. As diesel fuel volumes grow, the manufacturing cost may increase, depending upon how hydrodesulfurization technologies develop, whether significantly greater volumes of the diesel pool have to be desulfurized, to what degree other properties like aromatic levels have to be changed, and whether competitive fuel production technologies become economic. Low sulfur (10 parts per million) and low aromatics (10 volume percent) diesel fuel for the total market could require desulfurization, dearomatization, and hydrogen production investments amounting to a third of current refinery market value. The refinery capital cost component alone would be 3 cents per gallon of diesel fuel. Outside of refineries, the gas-to-liquids (GTL) plant investment cost would be 3 to 6 cents per gallon. With total projected investments of $\$ 11.8$ billion (6 to 9 cents per gallon) for the U.S. Gulf Coast alone, financing, engineering, and construction and material availability are major issues that must be addressed, for both refinery and GTL investments. 


\section{ULTRA-CLEAN DIESEL FUEL: U.S. PRODUCTION AND DISTRIBUTION CAPABILITY}

\section{EXECUTIVE SUMMARY}

Diesel engines have potential for use in a large number of future vehicles in the United States. However, to achieve this potential, proponents of diesel engine technologies must solve diesel's pollution problems, including objectionable levels of emissions of particulates and oxides of nitrogen. To meet emissions reduction goals, diesel fuel quality improvements could enable diesel engines with advanced aftertreatment systems to achieve the necessary emissions performance. It is likely that diesel fuel would have to be reformulated to be as clean as low sulfur gasoline.

Ultra-clean diesel fuel could be introduced into U.S. markets by options ranging from small incremental volumes to total market coverage. In this report, we examine the opposite ends of that range of possibilities. We first present an analysis which focuses on the relatively small volume requirement of light duty diesel fuel (LDDF); the U.S. refining system capability to produce LDDF with very low sulfur content; and infrastructure changes required to deliver low sulfur LDDF to consumers. Then we consider the U.S. refining system capability to produce a more severely reformulated diesel fuel (RFD) for all diesel vehicles.

\section{Small Market: Light Duty Diesel Fuel}

The probable route for refineries to produce low sulfur LDDF would involve changing blendstock selection. Blendstock change can be accomplished with relatively small capital investments within existing refineries (e.g., segregated tankage and related piping) and allows refiners to meet retail demand out of their own supply system. We use refinery industry survey data to estimate the potential of blendstock selection. If the LDDF sulfur specification is 10 to 15 parts per million (ppm), then the current U.S. refinery system could satisfy near to mid-term premised requirements for the LDDF market (5 to 10 percent of the highway diesel fuel market). However, combinations of hydrocracking and aggressive hydrotreating investments might be required to satisfy the long-term premised requirement for the LDDF market (20 percent of the highway diesel fuel market). The actual LDDF production strategy could include alternative supply sources that may compete at different product volume requirements.

The overall cost impacts of logistical and marketing changes for LDDF will depend to a large degree on how many players enter the LDDF market, whether there are significant operating problems due to the low volume and extra clean nature of the product, and the amount of new capital invested. At one end of the range, storage cost in existing terminal tanks is on the order 
of one-half cent per gallon per month for typical petroleum products. A small increment over this amount may be all the increased cost that LDDF faces for logistics. At the other end of the range, supplying this product may require long distance trucking or use of rail cars that, based on experience with ethanol and petroleum industry estimates, could add 10 cents per gallon for a long haul from distant terminals.

Refinery and distribution systems could produce adequate low sulfur blendstocks to satisfy near- to mid-term LDDF markets, and deliver that product to retail consumers with only modest changes. While blendstock production and infrastructure changes appear to be quite manageable, there are potential problems. There will be no LDDF market unless the Environmental Protection Agency requires retail fuel availability, "forcing" light duty diesel fuel vehicle operators to purchase the new fuel. Thereafter, market growth could eventually require significant refinery investment. LDDF is seen as possibly leading to similar quality requirements for the ten-times-larger market for fuel for heavy duty diesel vehicles. Initially, there could be poor economic returns on under-utilized infrastructure investments. Subsequent growth in the diesel fuel market could be inconsistent with U.S. refinery configurations and economics. As volumes grow, the manufacturing cost may increase, depending to a great extent on how hydrodesulfurization technologies develop, whether significantly greater volumes of the diesel pool have to be desulfurized for heavy duty diesel vehicle use, to what degree other properties like aromatics content have to be changed, and whether competitive fuel technologies like coaland gas-derived liquids production become economic.

\section{Large Market: Reformulated Diesel Fuel}

If sufficient volumes of RFD can be produced at a reasonable cost, then the full market potential for advanced light and heavy-duty diesel vehicles could be realized. With an adequate supply outlook for RFD, policy makers could better defend current activities like the promotion of diesel engine technologies in vehicles developed through the Partnership for a New Generation of Vehicles. However, if it is shown that RFD cannot be supplied at reasonable volumes and costs, then policy makers can make informed and appropriate responses, for example, by defining new research programs for diesel engine combustion or aftertreatment catalysts.

While the actual changes needed in future diesel fuels are not known, we have assumed that refineries would produce RFD by reducing the sulfur (to $10 \mathrm{ppm}$ ) and aromatics content (to 10 volume percent). In addition to reformulation of diesel fuel, we have assumed that vehicle fleet changes will result in a significantly greater fraction of RFD and a lesser fraction of gasoline. With the total diesel fuel market, RFD would simply displace diesel fuel in an expanded version of the current distribution system, and would not be subject to the logistics problems of the smaller volume LDDF market. However, a large demand for RFD could have significant impacts on: shifts in diesel fuel blendstocks, possibly including refinery purchases of ultra-clean 
blendstocks from gas-to-liquids (GTL) plants; refinery investment; refinery operating costs, fuel product costs; refinery energy use; refinery viability; refinery technology; and global shifts in production and imports/exports of distillates and gasoline.

We present an evaluation of the first two items in the list of significant impact areas (shifts in diesel fuel blendstocks and refinery investment), highlighting the types and costs of refinery changes required to make RFD. Results are based on a qualitative analysis drawn from limited published information, and projected impacts should be viewed as preliminary and directional in nature, with the understanding that required changes will differ among individual refineries.

We assume that RFD will be required in year 2005 for all diesel vehicles, and low sulfur gasoline will be required for gasoline-powered vehicles, and we also assume that greater volumes and proportions of diesel fuel will be required. To achieve RFD quality and production requirements, refiners will have to improve the quality of blendstocks through operational changes and investment in desulfurization and dearomatization technologies. Additionally, we should expect changes in volume percentages of blendstocks because of process operational changes, and introduction of ultra-clean stocks from GTL technologies.

A spreadsheet technique has been used to derive a blendstock mix which could satisfy RFD requirements. The technique accounts for blendstock quality improvements through operational changes, limits on refinery stream availability, and the plausibility of alternate disposition of streams within the refinery. Production of blendstocks for RFD will require rebalancing of refinery operations, resulting in a 15 percent reduction in gasoline production. The fluid catalytic cracker and hydrocracker processes will shift from gasoline to distillate production modes. There will be adjustments in the utilization of refinery gasoline production processes (e.g., reformers, alkylation, etc); Fischer-Tropsch (F-T) blendstocks will be purchased from GTL plants; and substantial refinery investment will be required. Sixty percent of the refineries in the study region (U.S. Gulf Coast) would invest in deep desulfurization and dearomatization capacity with total refinery investment of $\$ 3.8$ billion for the region.

The RFD sulfur specification can be achieved, albeit with virtually no margin for blending error, with refinery processes. However, to satisfy the RFD aromatics specification, aromatics-free F-T blendstocks must be purchased. Therefore, the aromatics specification could have a big influence on RFD production and on the use of ultra low sulfur/low aromatics blendstocks (like F-T) for compliance strategies. Refinery investment in desulfurization, dearomatization, and hydrogen production would be about a third of current refinery market value. The refinery capital cost component alone would be 3 cents per gallon of RFD. Outside of refineries, the GTL capital cost component would be 3 to 6 cents per gallon of RFD. With total projected investments of $\$ 11.8$ billion ( 6 to 9 cents per gallon)for the U.S. Gulf Coast alone, financing, engineering, and construction and material availability are major issues that must be addressed, for both refinery and GTL investments. 


\section{ULTRA-CLEAN DIESEL FUEL: U.S. PRODUCTION AND DISTRIBUTION CAPABILITY}

\section{BACKGROUND}

Diesel engines have potential for use in a large number of future vehicles in the United States. However, to achieve this potential, proponents of diesel engine technologies must solve diesel's pollution problems, including objectionable levels of emissions of particulates and oxides of nitrogen. To meet emissions reduction goals, diesel fuel quality improvements could enable diesel engines with advanced aftertreatment systems to achieve the necessary emissions performance, and it is likely that diesel fuel would have to be reformulated to be as clean as low sulfur gasoline.

In May, 1999, the U.S. Environmental Protection Agency (EPA) announced that it was considering requiring improvements in the quality of diesel fuel to enable advanced technologies for diesel emission control (Advance Notice of Proposed Rulemaking [ANPRM] on "Diesel Fuel Quality," U.S. EPA, 1999a). The EPA Regulatory Announcement summarized key issues in the ANPRM (U.S. EPA, 1999b):

"Diesel engines used to power trucks, buses, some automobiles, and nonroad equipment (such as tractors and bulldozers) are major contributors to our nation's air quality problems. Although progress has been made over the last decade in reducing emissions from diesels, they continue to be a large source of oxides of nitrogen (NOx) and diesel particulate matter (PM). NOx contributes to ground-level ozone, the main ingredient in smog. Diesel PM causes adverse respiratory health effects, and is also thought to pose a potential cancer risk. In addition to the impacts of emissions from heavy-duty and nonroad diesel engines, automobile manufacturers are planning to expand the use of diesels in sport utility vehicles and other fast-selling light-duty vehicles over the next few years. This may greatly add to the diesel's impact on the environment.

To reduce environmental impacts of diesel emissions, EPA is considering requiring improvements in the quality of diesel fuel. New diesel emission control technologies are being developed with the potential to reduce NOx emissions by 50 to 75 percent, and PM emissions by over 80 percent. However, some of these technologies appear to be very sensitive to sulfur in the fuel. Currently, highway diesel fuel sulfur is regulated to a maximum of 500 parts per million (ppm) and nonroad diesel fuel is not regulated by EPA at all. Diesel engine manufacturers have projected that sulfur levels must be reduced to 30 ppm, or perhaps even lower, to enable these sulfur-sensitive technologies to work. 
This advance notice is tied closely to EPA's recent proposal for Tier 2 emissions standards for passenger cars and light trucks, including sport utility vehicles, pickup trucks, and minivans. Under these standards, diesel vehicles would have to meet the same standards as gasoline vehicles. As part of the Tier 2 program, EPA also proposed to lower sulfur levels in gasoline, in part because it will enable catalyst technologies to achieve the new standards. With this ANPRM, the Agency is seeking comment on the merits of improving the quality of diesel fuel as well, as an enabler of advanced technologies for diesel emission control, without which diesel vehicles may not be able to meet Tier 2 standards. These technologies, if proven viable, would likely transfer to heavy-duty highway applications, and eventually to nonroad applications, yielding large NOx and PM benefits.

The advance notice seeks comment on many issues related to diesel fuel quality control, including:

1. Should fuel parameter changes other than sulfur reduction be pursued?

2. How effective will advanced sulfur-sensitive emission control technologies be?

3. What sulfur levels are needed and when?

4. What would the refinery and distribution costs be?

5. How soon can low sulfur fuel be made?

6. What would be the impact on small refiners?

7. How can the program be made flexible for refiners and still be effective?

8. Would a phased approach be appropriate, such as an early introduction of low-sulfur fuel for light-duty vehicles affected by the Tier 2 program?

9. Should nonroad fuel be desulfurized to current highway fuel quality levels?"

In May, 2000, EPA published its Notice of Proposed Rulemaking (NPRM) for "Control of Air Pollution from New Motor Vehicles: Proposed Heavy-Duty Engine and Vehicle Standards and Highway Diesel Fuel Sulfur Control Requirements.” The NPRM included a proposal to reduce highway diesel fuel sulfur to $15 \mathrm{ppm}$, a 97 percent reduction from the current maximum allowable sulfur content (U.S. EPA, 2000).

This report addresses manufacturing cost issues, with consideration of phased and non-phased introduction of ultra-clean diesel fuel (issues 4 and 8 in the Regulatory Announcement above). 
Because of the increased processing difficulty and costs for fuel property improvements, demand for ultra-clean diesel fuel could present technical and economic challenges for the U.S. refining industry. It is important to the national economy and security that these challenges to the U.S. refining industry do not adversely affect the efficiency and reliability of the transportation fuel production and distribution system.

Ultra-clean diesel fuel could be introduced into U.S. markets by options ranging from smaller incremental volumes to total market coverage. In this report, we examine the opposite ends of that range of possibilities. We first present an analysis which focuses on the relatively small volume requirement of light duty diesel fuel (LDDF); the U.S. refining system capability to produce small amounts of LDDF with very low sulfur content (30 ppm or less); and infrastructure changes required to deliver low sulfur LDDF to consumers. Then we consider the U.S. refining system capability to produce a more severely reformulated diesel fuel (10 ppm sulfur and 10 volume percent aromatics) for all diesel vehicles. 


\section{CURRENT DIESEL FUEL MARKET STRUCTURE}

The current LDDF market serves approximately 1 million vehicles (primarily heavier light duty trucks manufactured in the last 5 years and older passenger cars) through traditional retail fuel outlets and truck stops. Estimates by consultants and fuel retailers of this retail refueling system indicate that diesel fuel is currently available at approximately 1 in 6 retail outlets that serve the light duty vehicle (LDV) market. This is augmented, primarily along the interstate highway system, by about 5000 "truck stops" that sell diesel fuel to heavy duty diesel vehicles (HDDVs), most commonly the over-the-road truck, as well as LDVs. The same fuel, on-road low sulfur diesel (currently required to not exceed 500 ppm sulfur), is sold to LDVs and HDDVs, regardless of retail outlet type. The stations selling to both vehicle types typically have segregated fuel dispensers, with LDDF being sold from dispensers on the same islands as the ordinary gasoline dispensers. This diesel fuel is delivered to essentially all of these retail outlets by over-the-road tanker trucks, hauling from bulk product terminals, refineries and some limited number of bulk plants at distances usually not greater than 100 miles.

The light duty diesel vehicle (LDDV) market is growing rapidly with between 250,000 and 300,000 new vehicles (primarily heavier light trucks and a few new models of passenger cars) added to the fleet annually. Based on estimates of the existing LDDV fleet, the U.S. Department of Energy (DOE) concludes that currently 50 thousand to 100 thousand barrels per day (MBD) of diesel fuel are purchased by these LDDV end users, with most purchases through the retail outlets. Fleet, construction and agriculture users of LDDF may be purchasing some of their on-road fuel in bulk, rather than through retail outlets, but that volume cannot be reliably estimated.

With the introduction of more new diesel passenger car and light duty truck models in the next few years, one can make a reasonable estimate that by the time Tier 2 emissions standards require the introduction of a new clean LDDF (assumed for the purpose of this report to be year 2005), this market will be using between 100 MBD and 200 MBD of diesel fuel in several million LDVs. DOE has not attempted to estimate how rapidly this market may grow beyond this time horizon. However, estimates for the American Petroleum Institute indicate a possible range of LDDF needs from $250 \mathrm{MBD}$ to $400 \mathrm{MBD}$ in year 2010 (Little, 1999). 


\section{SMALL MARKET: LIGHT DUTY DIESEL FUEL}

\subsection{POTENTIAL LDDF SOURCES AND COST}

Because of the relatively low volume of LDDF that is estimated to be needed to serve the market, there is a greater number of potential fuel production options than is the case for a high volume product like the low sulfur gasoline that is proposed as part of the Tier 2 rulemaking. These options include:

Blendstock selection (“cherry picking") within current refinery configurations and operations,

Operational changes within existing refinery configurations for on-purpose production of LDDF blendstocks in which certain unit operations are increased or reduced for limited periods of time,

Alternative crude oil choices for ongoing or limited periods of time,

On-purpose refinery investment in aggressive hydrodesulfurization technology and supporting units,

Imports from foreign refineries, with the heavy hydrocracking European refineries a likely source, and

Diesel fuels and blendstocks derived from coal- and gas-derived liquids production in existing and new projects now under construction or in planning.

A number of refining industry experts expect that the first option of blendstock selection will be pursued as the preferred route to providing the necessary volumes of this low sulfur diesel fuel. Blendstock selection requires relatively small capital investments within existing refineries (e.g., segregated tankage and related piping) and allows refiners to meet retail demand out of their own supply system. We estimate the potential of the blendstock selection alternative using certain key assumptions (McNutt, 2000). With our focus on the sulfur property of LDDF, we presume that the refining system will make appropriate responses to maintain other properties, such as cetane number and pour point. The current LDV demand for LDDF is estimated to be 5 percent (about $100 \mathrm{MBD}$ ) of the highway diesel fuel market. We assume that LDDF demand will be 10 percent of the highway diesel fuel market in year 2004, and 20 percent of the market in year 2008 . 
The estimate of blendstock availability is based on relatively simple spreadsheet calculations with data drawn from limited published information. Sophisticated refinery modeling would be required to estimate blendstock allocations to satisfy all specifications, and to account for production changes due, for example, to anticipated growth in jet fuel demand. Therefore, findings should be viewed as preliminary and directional in nature, with recognition that different changes will be required for each individual refinery.

In this analysis, production volumes of distillate blendstocks, reported in an industry survey, have been totaled by sulfur content (API/NPRA, 1997). The survey covers 87 percent of U.S. refinery crude distillation capacity. Production volumes may not be scalable (to 100 percent of U.S. refinery crude distillation capacity) without significant error, and volumes have not been scaled-up in our totals. The survey also reports process utilization. With these utilization data, production volumes, by sulfur content, have been totaled for maximum practical utilization of hydrotreating and hydrogen production capacity. Table 1 shows the range of sulfur values for different blendstocks reported in the survey.

Table 1. Diesel Fuel Blendstock Sulfur in 1996

\begin{tabular}{|c|c|c|}
\hline Blendstock & Sulfur ppm & Key processes* \\
\hline \multicolumn{3}{|l|}{ Straight-run: } \\
\hline Light distillate $\left(350-500^{\circ} \mathrm{F}\right)$ & $290-1800$ & Crude \\
\hline Heavy distillate $\left(500-650^{\circ} \mathrm{F}\right)$ & $690-6400$ & Crude \\
\hline Light gas oil $\left(650-700^{\circ} \mathrm{F}\right)$ & 7500 & Crude \\
\hline \multicolumn{3}{|l|}{ Cracked unhydrotreated: } \\
\hline Light distillate & 2200 & FDS, FCC \\
\hline Heavy distillate & $2700-4800$ & FDS, FCC \\
\hline Light gas oil & 5500 & FDS, FCC \\
\hline \multicolumn{3}{|l|}{ Coked, unhydrotreated: } \\
\hline Light distillate & 2200 & Coker \\
\hline Heavy distillate & 5100 & Coker \\
\hline \multicolumn{3}{|c|}{ Hydrotreated (Non-cracked and cracked): } \\
\hline Light distillate & $10-350$ & HDS, H2 \\
\hline Heavy distillate & $80-1200$ & HDS, H2 \\
\hline Light gas oil & $20-2400$ & FDS, FCC, HDS, H2 \\
\hline \multicolumn{3}{|l|}{ Hydrocracked: } \\
\hline Light distillate & $7-12$ & HCR, H2 \\
\hline Heavy distillate & $10-270$ & $\mathrm{HCR}, \mathrm{H} 2$ \\
\hline
\end{tabular}

*Crude - crude distillation; FDS - desulfurization of fluid catalytic cracker (FCC) feed; HDS hydrotreating. H2 - hydrogen production. HCR - hydrocracking. 


\subsection{POTENTIAL LDDF PRODUCTION}

Analysis of survey data shows that, with reported process utilization and blending practice (Figure 1 dashed line), 5 percent of the highway diesel fuel market could be supplied with LDDF sulfur at 10 to $15 \mathrm{ppm}$; 10 percent of the market could be supplied with LDDF at 15 to $20 \mathrm{ppm}$; and 20 percent of the market could be supplied with LDDF sulfur of $60 \mathrm{ppm}$. Furthermore, the current U.S. highway diesel fuel sulfur specification (500 ppm maximum) would be satisfied for fuel remaining after segregation of low sulfur blendstocks. Low sulfur blends, however, may need additional processing to satisfy specifications such as cetane number.

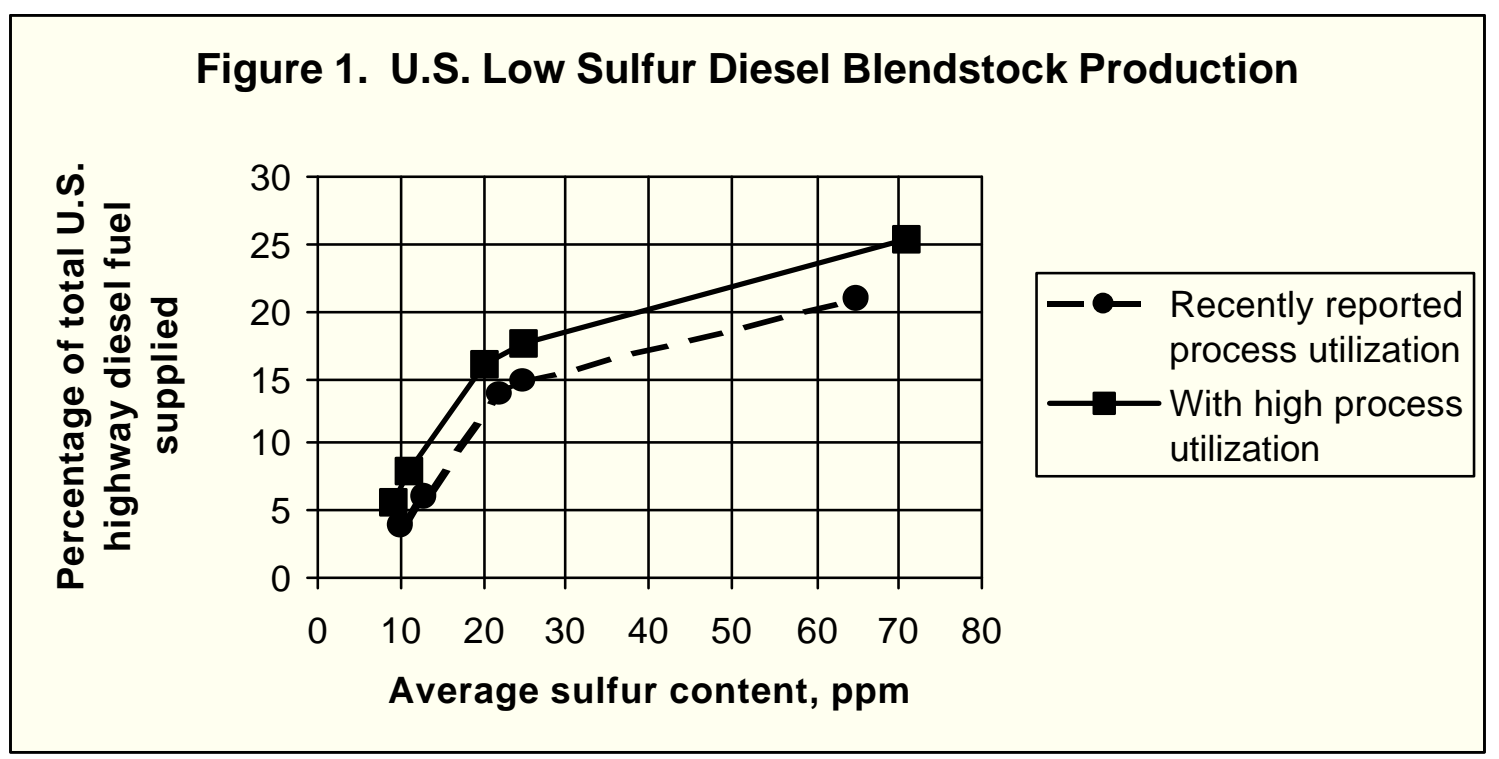

With practical maximum refinery process utilization (Figure 1 solid line), there are small sulfur reductions for given production volumes of LDDF. Five percent of the highway diesel fuel market could be supplied with LDDF sulfur at 10 ppm.; 10 percent of the market could be supplied with LDDF sulfur at 10 to $15 \mathrm{ppm}$; and 20 percent of the market could be supplied with LDDF sulfur at 40 ppm.

Low sulfur LDDF blendstock production patterns are geographically uneven. Figure 2 shows that California is the predominant source of low sulfur distillate blendstocks, with production of half of U.S. blendstocks with sulfur at $15 \mathrm{ppm}$, and three-fourths of U.S. blendstocks with sulfur at 10 ppm. Currently, U.S. refineries supply 97 percent of U.S. highway diesel fuel. The ratio of highway diesel fuel production to crude input is about equal for the surveyed refineries in California compared to the rest of the United States. It is reasonable to conclude, as suggested in Figure 3, that a California-type refining system could supply 25 percent of U.S. demand for LDDF at 10 ppm sulfur. California blendstocks with less than $10 \mathrm{ppm}$ sulfur have been hydrocracked. Table 2 shows that the California refinery system has much greater 

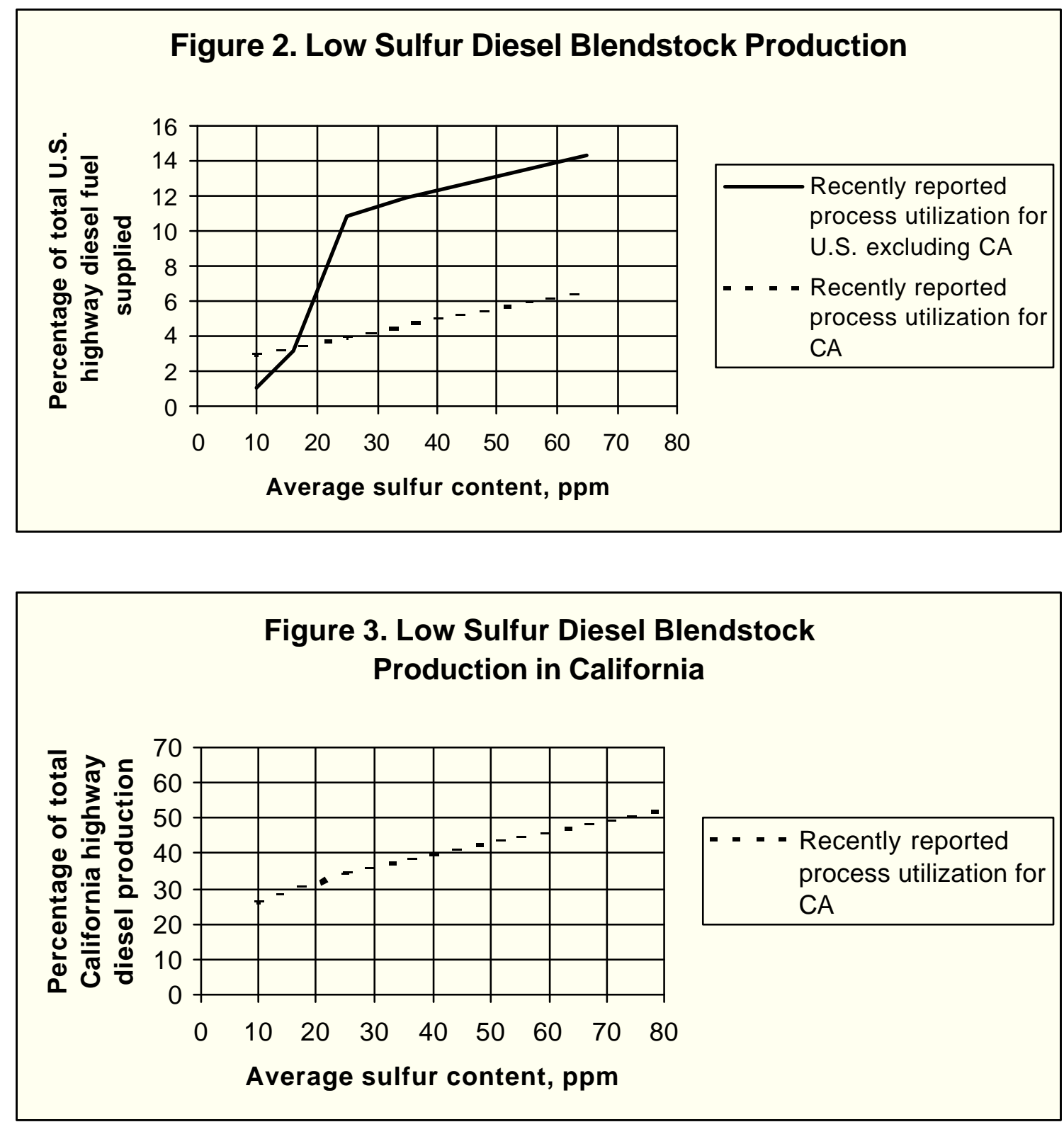

relative hydrocracking and hydrogen capacity, compared to refineries in the rest of the United States.

Table 2. Refining Systems for Production of Low Sulfur Blendstocks for LDDF

\begin{tabular}{|ccc|}
\hline Capacity ratios for surveyed refineries & California & Rest of U.S. \\
\hline Hydrocracking:crude & 0.30 & 0.08 \\
$\begin{array}{c}\text { Hydrogen generation:crude } \\
\text { stream day) }\end{array}$ & 0.6 & 0.1 \\
(thousand standard cubic feet per day: barrels per & & \\
\hline
\end{tabular}


A processing option less severe than hydrocracking is aggressive hydrotreating (with 99 percent sulfur reduction), which might supply 20 percent of the market with LDDF at 20 ppm sulfur. Aggressive hydrotreating would require process unit changes for new requirements for space velocity, hydrogen, etc.

In summary, if the LDDF sulfur specification is 10 to $15 \mathrm{ppm}$, then the current U.S. refinery system could satisfy near to mid-term premised requirements for the LDDF market (5 to 10 percent of the highway diesel fuel market). However, combinations of hydrocracking and aggressive hydrotreating investments might be required to satisfy the long-term premised requirement for the LDDF market (20 percent of the highway diesel fuel market). The actual LDDF strategy could include alternative supply sources that may compete at different product volume requirements.

\subsection{POSSIBLE REGULATORY REQUIREMENTS TO ASSURE LDDF AVAILABILITY}

There are a number of possible regulatory actions EPA could take in an effort to assure that a diesel fuel of the needed quality is available in the market place for LDDV operators to purchase. A number of these approaches are discussed in the ANPRM. If the primary goal is to assure that this fuel is available to and used in LDDVs that require it to protect emission control systems, it appears that the most economic and straightforward approach is to require that all (or most) retail outlets selling diesel fuel have available LDDF of the required quality. This could be combined with a fuel dispenser nozzle size requirement and pump labeling that would help assure that only LDDF could be dispensed into new vehicles requiring such fuel. This approach is parallel to that employed by EPA with the introduction of unleaded gasoline in the early 1970s.

Modification of this approach might be required if it appears that obtaining this fuel at the wholesale terminal level will be problematic for retailers. EPA may want to consider whether retailers should have an opportunity to make a argument about a lack of wholesale availability or other hardships that would allow them more time to comply with the retail availability requirement (such retailers would still have to comply with the nozzle sizing and pump labeling requirements to avoid misfueling). This flexibility would avoid forcing retailers out of the LDDF market due to circumstances beyond their control. Alternatively, EPA could consider extending the availability requirement to the bulk product terminal level, perhaps limited to terminals above a certain capacity or throughput volume. However, given the normal business operation of many terminals where the terminal operator does not own the product, the uneven geographic distribution of terminals, and the other potential sources of the product, it is hard to see how such a requirement might be reasonably applied. In no case does DOE see a need or a cost-effective way to apply a production requirement to fuel producers. 
Given the current widespread retail availability of LDDF, DOE does not foresee a need for EPA to extend the availability requirement beyond current LDDF retailers. The analysis in the literature of alternative fuel availability indicates that the availability of the fuel at 15 to 20 percent of retail outlets is fully adequate to meet diesel vehicle operators' refueling needs (Greene, 1998). Unlike many of the existing alternative fuel vehicles, diesel vehicles have, by virtue of their high efficiency and fuel density, extended range to overcome virtually any refueling concerns. The analysis that has been done and the strong existing market for LDDVs demonstrate that the limited extent of the current LDDF refueling infrastructure is not a problem for diesel vehicle operators nor one that EPA needs to address at this point.

\subsection{COST OF ASSURING RETAIL LDDF AVAILABILITY}

While a retail fuel availability requirement would apply to the owners or operators of retail outlets, the structure of that requirement discussed above is such that the retailer would face little cost to meet it. No new tanks or pumps would be required for most retailers unless the retailer believed it was economically attractive to sell two grades of diesel fuel to the light duty market. Some "truck stops" might face new tankage requirements if existing tankage did not allow one tank to be devoted to the new light duty fuel. Some changes in supply arrangements might be required (use of alternative terminals or suppliers), which could increase the cost of the product delivered to the retail outlet. However, competitive impacts would be limited as all retailers in an area would likely face similar circumstances.

The largest share of the operating and economic burdens to meet this fuel availability requirement will fall on wholesale fuel providers and terminal operators (often one and the same) who want to be able to continue to supply diesel fuel to their light duty vehicle retail markets. The capital cost of additional tankage, associated lines and loading systems will vary with tank size and terminal configuration. At smaller to mid-sized petroleum product bulk terminals, a 20 thousand barrel (MB) tank may be typical and have a capital cost in the range of $\$ 300,000$. Loading system and line requirements can make the total cost double that of tanks alone. Tanks as large as $100 \mathrm{MB}$ can be used in the larger terminals and enjoy economies of scale relative to the smaller tanks but may not be likely for a low volume product such as LDDF. Some terminals may have available unused tankage, but this option is likely to be very limited as the terminal part of the fuel supply industry has undergone considerable consolidation (NPC, 1998).

There are an estimated 1,500 to 2,000 petroleum product bulk terminals in the U.S. primary distribution system, situated to receive product by pipeline or water. These terminals and refineries themselves, not the larger number of much smaller petroleum product bulk plants in the U.S. secondary distribution system (estimated to be in the range of 10,000), are the most likely source for distribution of LDDF to retail outlets. Some small fraction of these terminals will have to add or convert capacity to accommodate this new product. However, it is difficult 
and highly speculative, at this point, to estimate total costs because of the large uncertainty in how the distribution system will adapt to provide the product at relatively low volumes to only about 20 percent of retail outlets. For marketers in more rural or logistically isolated areas, most of the terminals and even some of the bulk plants may need to have the new fuel available to efficiently serve retail outlets. In major urban areas, where the majority of bulk terminals are located, a much smaller fraction of the terminals will likely carry the new product, and retail needs will be served through exchange agreements between marketers.

DOE has not yet estimated the overall impact of these necessary logistical and marketing changes on the cost of LDDF. It will depend to a large degree on how many players enter the LDDF market, whether there are significant operating costs (such as extra cleaning and maintenance or increased pipeline transmix to be handled) due to the low volume and extra clean nature of the product, and the actual amount of new capital invested. At one end of the range, storage cost in existing terminal tanks is on the order of one-half cent per gallon per month for typical petroleum products. A small increment over this amount may be all the increased cost that LDDF faces for logistics. At the other end of the range, supplying this product may require long distance trucking or use of rail cars that, based on experience with ethanol and petroleum industry estimates, could add 10 cents per gallon for a long (e.g., several hundred miles) haul from distant terminals. DOE believes that a probable cost of several cents per gallon can be assumed until better data become available.

\subsection{LDDF SYSTEM ADEQUACY}

Refinery and distribution systems could produce adequate low sulfur blendstocks to satisfy near- to mid-term LDDF markets, and deliver that product to retail consumers with only modest changes. While blendstock production and infrastructure changes appear to be quite manageable, there are potential problems. There will be no LDDF market unless EPA requires retail fuel availability, "forcing" LDDV operators to purchase the new fuel. Thereafter, market growth could eventually require significant refinery investment. LDDF is seen as possibly leading to similar quality requirements for the ten-times-larger market for fuel for HDDVs. Initially, there could be poor economic returns on under-utilized infrastructure investments. Subsequent growth in the diesel fuel market could be inconsistent with U.S. refinery configurations and economics.

The potential to produce relatively small volumes of LDDF at very low incremental cost within existing refineries, and the many other possible approaches to its production, suggests that the incremental manufacturing cost of this product will be very low at the time of its initial use. As volumes grow, the manufacturing cost may increase. But, this depends to a great extent on how hydrodesulfurization technologies develop, whether significantly greater volumes of the diesel pool have to be desulfurized for heavy duty diesel vehicle use, to what degree other properties 
like aromatics content have to be changed, and whether competitive fuel technologies like coaland gas-derived liquids production become economic. 


\section{LARGE MARKET: REFORMULATED DIESEL FUEL}

If sufficient volumes of reformulated diesel fuel (RFD) can be produced at reasonable cost, then the full market potential for advanced light and heavy-duty diesel vehicles could be realized. With an adequate supply outlook for RFD, policy makers could better defend current activities like the promotion of diesel engine technologies in vehicles developed through the Partnership for a New Generation of Vehicles. However, if it is shown that RFD cannot be supplied at reasonable volumes and costs, then policy makers can make informed and appropriate responses, for example, by defining new research programs for diesel engine combustion or aftertreatment catalysts.

While the actual changes needed in future diesel fuels are not known, we have assumed that petroleum refineries would produce RFD by reducing the sulfur and aromatics contents. In addition to reformulation of diesel fuel, we have assumed that vehicle fleet changes will result in a significantly greater fraction of RFD and a lesser fraction of gasoline. With the total diesel fuel market, RFD would simply displace diesel fuel in an expanded version of the current distribution system, and would not be subject to the logistics problems of the smaller volume LDDF market. However, a large demand for RFD could have significant impacts on:

Shifts in diesel fuel blendstocks, possibly including refinery purchases of ultra-clean blendstocks from gas-to-liquids (GTL) plants,

Refinery investment,

Refining costs, fuel product costs, and refinery energy use,

Refinery viability,

Refinery technology, and

Global shifts in production and imports/exports of distillates and gasoline.

We present an evaluation of the first two items in the list of significant impact areas, highlighting the types and costs of refinery changes required to make RFD (McNutt and Hadder, 1998). As in the LDDF analysis, results are based on a qualitative analysis drawn from limited published information. No new quantitative analysis or modeling has been done. Therefore, projected impacts should be viewed as preliminary and directional in nature, with the understanding that required changes will differ among individual refineries. 


\subsection{RECENT DIESEL FUEL PRODUCTION}

Tables 3 and 4 show recent diesel fuel production and quality data (U.S. DOE, 1998; API/NPRA, 1997). For the combined regions listed in the tables, the average sulfur content of diesel fuel sulfur is well above 340 ppm and the average aromatics content is above 31 volume percent. Because Petroleum Administration for Defense District III (PADD III, U.S. Gulf Coast) produces the greatest amount of diesel fuel, the analysis of RFD production will focus on that region.

Table 3. Diesel Fuel Production in 1997 for U.S. Excluding PADD V (West Coast)

\begin{tabular}{|lccc|}
\hline \multicolumn{1}{|c}{ Fuel } & $\begin{array}{c}1000 \text { barrels per day } \\
\text { (MBD) }\end{array}$ & Sulfur ppm & $\begin{array}{c}\text { Aromatics } \\
\text { vol percent }\end{array}$ \\
\hline Low sulfur diesel & 1810 & 340 & 32 \\
Off- road diesel & $>480$ & 3000 & 31 \\
\hline
\end{tabular}

Source: U.S. DOE, 1998; API/NPRA, 1996

Table 4. U.S. Regional Production of Low Sulfur Diesel Fuel in 1997

\begin{tabular}{|lc|}
\hline \multicolumn{1}{|c|}{ Region } & $\begin{array}{c}\text { Percent of total PADD I - PADD IV } \\
\text { production }\end{array}$ \\
\hline PADD I (East Coast) & 8 \\
PADD II (Midwest) & 33 \\
PADD III (Gulf Coast) & 53 \\
PADD IV (Rocky Mountain) & 6 \\
\hline
\end{tabular}

Source: U.S. DOE, 1998

Typical blendstocks for low sulfur diesel fuel produced in PADD III are summarized in Table 5 (which presents a somewhat different aggregation of blendstocks than Table 1 to simplify the analysis). Table 5 shows only two blendstocks (hydrotreated and hydrocracked light distillate) with sulfur contents less than $100 \mathrm{ppm}$. These blendstocks comprise only 7 volume percent of the low sulfur diesel fuel product (API/NPRA, 1997). 
Table 5. Typical Blendstocks for Low Sulfur Diesel Fuel in PADD III

\begin{tabular}{|lcccc|}
\hline \multicolumn{1}{|c}{ Blendstock } & $\begin{array}{c}\text { Vol } \\
\text { percent }\end{array}$ & $\begin{array}{c}\text { Sulfur } \\
\text { ppm }\end{array}$ & $\begin{array}{c}\text { Aromatics vol } \\
\text { percent }\end{array}$ & $\begin{array}{c}\text { Key } \\
\text { processes* }\end{array}$ \\
\hline Straight-run & 10 & 570 & 27 & CRU \\
Cracked unhydrotreated & 1 & 4400 & 40 & FDS, FCC \\
\hline Hydrotreated (Non-cracked and cracked): & 1 & $430(?)$ & 11 & HDS, H2 \\
\hline Naphtha $\left(200-370{ }^{\circ} \mathrm{F}\right)$ & 6 & 70 & 21 & HDS, H2 \\
Light distillate $\left(350-500^{\circ} \mathrm{F}\right)$ & 71 & 540 & 39 & HDS, H2 \\
Heavy distillate $\left(500-650^{\circ} \mathrm{F}\right)$ & 6 & 1000 & 50 & FDS, FCC, \\
Light gas oil $\left(650-700^{\circ} \mathrm{F}\right)$ & & & & HDS, H2 \\
\hline Hydrocracked: & 1 & 10 & 31 & HCR, H2 \\
\hline Light distillate & 3 & 270 & 24 & HCR, H2 \\
\hline Heavy distillate & & & & \\
\hline
\end{tabular}

*CRU - crude distillation; FDS - desulfurization of feed for fluid catalytic cracker (FCC); HDS - hydrotreating; H2 - hydrogen production; HCR - hydrocracking.

Source: API/NPRA, 199

\subsection{RFD ASSUMPTIONS}

We assume that RFD will be required in year 2005 for all diesel vehicles, and low sulfur gasoline will be required for gasoline-powered vehicles. Greater volumes and proportions of diesel fuel will be required. Current (1997) diesel fuel production in PADD III is 960 MBD, or 12 percent of total production of refined products in that region (U.S. DOE, 1998).

Production of RFD in year 2005 is assumed to be 1450 MBD, which is based on an assumed 25 percent increase in on-road diesel fuel to satisfy new LDV demand and expected growth in current HDDV markets, plus constant production of off-road diesel fuel. Table 6 shows that the premised RFD will have very low sulfur and aromatics contents. T90 will be lower and cetane number will be higher. We also assume that additive technologies will be developed so that acceptable diesel fuel qualities such as lubricity and pour point can be maintained. 
Table 6. Reformulated Diesel Fuel Assumed Requirements

\begin{tabular}{|l|c|}
\hline Production in PADDs I - IV & $2740 \mathrm{MBD}^{*}$ \\
\hline Production in PADD III & $1450 \mathrm{MBD}^{*}$ \\
\hline Sulfur ppm, maximum & 30 \\
\hline Aromatics vol percent, maximum & 10 \\
\hline Cetane number & Higher \\
\hline T90 & Lower \\
\hline Lubricity** & Maintain quality \\
\hline Pour*** & Current specifications \\
\hline Flash point, etc. & Current specifications \\
\hline
\end{tabular}

*On-road diesel fuel with an assumed 25 percent increase to meet increased Light Duty

Vehicle demand plus off-road diesel fuel.

**Lubricity can be degraded with hydrocracked blendstocks.

***Fischer-Tropsch (F-T) blendstocks can have high pour points.

\subsection{RFD PRODUCTION}

To achieve RFD quality and production requirements, refiners will have to improve the quality of blendstocks through operational changes and investment in desulfurization and dearomatization technologies. Additionally, we should expect changes in volume percentages of blendstocks through operational changes in the hydrocracker, and introduction of ultra-clean stocks from GTL technologies.

A spreadsheet technique has been used to derive a blendstock mix to satisfy RFD requirements. The technique accounts for blendstock quality improvements through operational changes, limits on refinery stream availability, and the plausibility of alternate disposition of streams within the refinery. RFD blendstocks are shown in Table 7, with volume percentages, sulfur and aromatics contents, and key processes for blendstock production. Production of blendstocks for RFD will require rebalancing of refinery operations, with a 15 percent reduction in gasoline production. The fluid catalytic cracker and hydrocracker will shift from gasoline to distillate production modes. There will be adjustments in the utilization of gasoline production processes (e.g., reformers, alkylation, etc), Fischer-Tropsch (F-T) blendstocks will be purchased from GTL plants, and there will be substantial refinery investment. We use SynSat (licensed by ABB Lummus Crest Inc./Criterion Catalyst Co.) to represent deep desulfurization and dearomatization technologies, although competitive technologies will be 
available from other licensors (Gulf Publishing Co., 1994). Refinery investment in SynSat and supporting hydrogen capacity is shown in Table 8. If typically-sized units were installed, then sixty percent of the refineries in PADD III would invest in SynSat capacity. Total refinery investment would be $\$ 3.8$ billion for the region.

Table 7. Blendstocks for Reformulated Diesel Fuel in PADD III

\begin{tabular}{|c|c|c|c|c|}
\hline Blendstock & $\begin{array}{c}\text { Vol } \\
\text { percent }\end{array}$ & $\begin{array}{c}\text { Sulfur } \\
\text { ppm }\end{array}$ & $\begin{array}{c}\text { Aromatics vol } \\
\text { percent }\end{array}$ & Key processes \\
\hline Straight-run & 0 & 570 & 27 & \\
\hline Cracked unhydrotreated & 0 & 4400 & 40 & \\
\hline \multicolumn{5}{|l|}{ Deep Hydrotreating: } \\
\hline Naphtha & nil & 10 & 10 & SynSat,*H2 \\
\hline Light distillate & 7 & 10 & 10 & SynSat, H2 \\
\hline Heavy distillate & 46 & 10 & 10 & SynSat, H2 \\
\hline Light gas oil & 11 & 10 & 10 & SynSat, H2 \\
\hline \multicolumn{5}{|l|}{ Hydrocracked: } \\
\hline Light distillate & 8 & 7 & 12 & HCR, H2 \\
\hline Heavy distillate & 12 & 10 & 21 & HCR, H2 \\
\hline \multicolumn{5}{|l|}{ Other: } \\
\hline F-T diesel (purchased) & 15 & 0 & 0 & GTL \\
\hline Total reformulated diesel & 100 & 8 & $10 * *$ & \\
\hline
\end{tabular}

*SynSat is hydrodesulfurization/dearomatization process licensed by ABB Lummus Crest Inc./Criterion Catalyst Co (Gulf Publishing Co., 1994).

**Binding specification. 
Table 8. Refinery Process Investment Including Offsites

(Based on: Gulf Publishing Co., 1994; Oak Ridge National Laboratory

Refinery Yield Model)

\begin{tabular}{|c|c|c|c|c|}
\hline \multirow[b]{2}{*}{ Process } & \multicolumn{2}{|c|}{ Typical Unit } & \multirow{2}{*}{$\begin{array}{l}\text { Total new } \\
\text { capacity in } \\
\text { PADD III }\end{array}$} & \multirow{2}{*}{$\begin{array}{c}\text { Total investment } \\
\text { in } \\
\text { PADD III, } \\
\text { million\$ }\end{array}$} \\
\hline & Size & $\begin{array}{c}\text { Cost } \\
\text { million\$ }\end{array}$ & & \\
\hline SynSat & $25 \mathrm{MBD}$ & 68 & $940 \mathrm{MBD}$ & 2600 \\
\hline Hydrogen production & $\begin{array}{l}60 \text { million } \\
\text { cubic feet } \\
\text { per day } \\
(\mathrm{MMcfd})\end{array}$ & 83 & $850 \mathrm{MMcfd}$ & 1200 \\
\hline Total & & & & 3800 \\
\hline
\end{tabular}

The RFD sulfur specification can be achieved, albeit with virtually no margin for blending error, with SynSat technology. However, the aromatics specification cannot be met unless cleanerthan-SynSat blendstocks are used. To satisfy the RFD aromatics specification, aromatics-free F-T blendstocks could be purchased. If the aromatics target had been 12 vol percent, instead of 10 vol percent, then F-T blendstocks would not have been used in the RFD production example. So, the aromatics specification could have a big influence on RFD production and on the use of ultra low sulfur/low aromatics blendstocks (like F-T) for compliance strategies.

Fifteen percent of RFD would be F-T blendstocks, and there would be no margin for aromatics blending error. Production of F-T for RFD would require an investment of $\$ 8$ billion in GTL processes, as shown in Table 9 (Pennwell Publishing Co., 1998). Capital costs are very sensitive to costs reported for SynSat and GTL investments. Operating costs are not estimated in this analysis.

Table 9. GTL Investment Including Offsites

(Based On: Pennwell Publishing Co., 1998)

\begin{tabular}{|lcccc|}
\hline Process & \multicolumn{2}{c}{ Typical Unit } & $\begin{array}{c}\text { Total new } \\
\text { capacity for } \\
\text { PADD III }\end{array}$ & $\begin{array}{c}\text { Total investment for } \\
\text { PADD III, } \\
\text { million } \$\end{array}$ \\
\cline { 2 - 4 } Size & $\begin{array}{c}\text { Cost } \\
\text { million } \$\end{array}$ & 1650 & $320 \mathrm{MBD}$ & 8000 \\
\hline GTL & $65 \mathrm{MBD}$ & 1650 \\
\hline
\end{tabular}




\section{CONCLUSIONS}

In this report, we have examined the small- and large-market extremes for introduction of ultraclean diesel fuel in the United States. We have concluded that refinery and distribution systems could produce adequate low sulfur blendstocks to satisfy the small markets for LDDF (with 30 ppm sulfur or less) in the near- to mid-term and to deliver LDDF to retail consumers with only modest changes. While LDDF production and infrastructure changes appear to be manageable, there are potential problems. There will be no LDDF market unless EPA requires retail fuel availability, "forcing" LDDV operators to purchase the new fuel. Initially, there could be poor economic returns on under-utilized infrastructure investments. Subsequent growth in the diesel fuel market could be inconsistent with U.S. refinery configurations and economics. As volumes grow, the manufacturing cost may increase. Manufacturing cost increases depend on how hydrodesulfurization technologies develop, whether significantly greater volumes of the diesel pool have to be desulfurized for HDDVs, to what degree other properties like aromatic content have to be changed, and whether competitive fuel technologies like GTL plants become economic.

Depending on the volume and specification requirements, RFD for the total diesel fuel market could be a "big deal" for refiners and others in the fuels industry. Refinery investment in desulfurization, dearomatization, and hydrogen production would be about a third of current refinery market value. The refinery capital cost component alone would be 3 cents per gallon of RFD. Outside of refineries, the GTL capital cost component would be 3 to 6 cents per gallon of RFD. With total projected investments of $\$ 11.8$ billion ( 6 to 9 cents per gallon) for

the U.S. Gulf Coast alone, financing, engineering, and construction and material availability are major issues that must be addressed, for both refinery and GTL investments. 


\section{REFERENCES}

(API/NPRA) American Petroleum Institute/National Petroleum Refiners Association. (1997). 1996 American Petroleum Institute/National Petroleum Refiners Association Survey of Refining Operations and Product Quality, Washington, DC, July.

Greene, D. L. (1998). "Survey Evidence on the Importance of Fuel Availability to the Choice of Alternative Fuels and Vehicles," Energy Studies Review, October.

Gulf Publishing Co. (1994). "Refining Processes ‘94,” Hydrocarbon Processing, November.

Little, Arthur D. (1999). “U.S. Light-duty Dieselization Scenarios-Preliminary Study,” Final Report to the American Petroleum Institute, June 7.

McNutt, Barry. (2000). "Reformulated Diesel Fuel - U.S. Refinery Production Capability," Proceedings of the 1999 Diesel Engine Emissions Reduction Workshop, DOE/EE-0214, Maine Maritime Academy, Castine, ME, sponsored by U.S. Department of Energy, Office of Transportation Technologies, Assistant Secretary for Energy Efficiency and Renewable Energy, Washington, DC 20585, July 5-9.

McNutt, Barry and Jerry Hadder. (1998). "Reformulated Diesel Fuel - The Challenge for U.S. Refineries," Proceedings of the 1998 Diesel Engine Emissions Reduction Workshop, DOE/EE-0191, Maine Maritime Academy, Castine, ME, sponsored by U.S. Department of Energy, Office of Transportation Technologies, Assistant Secretary for Energy Efficiency and Renewable Energy, Washington, DC 20585, July 6-9.

(NPC) National Petroleum Council. (1998). U.S. Petroleum Product Supply Inventory Dynamics, Washington, DC, December.

Pennwell Publishing Co. (1998). "Gas-to-liquids processing hits its stride," Oil \& Gas Journal, June 15.

(U.S. DOE) U. S. Department of Energy, Energy Information Administration. (1998). Petroleum Supply Annual 1997, June.

(U.S. EPA) U. S. Environmental Protection Agency. (2000). "Control of Air Pollution from New Motor Vehicles: Proposed Heavy-Duty Engine and Vehicle Standards and Highway Diesel Fuel Sulfur Control Requirements," Notice of Proposed Rulemaking, 40 CFR Parts 80, 85, and 86, May 17, http://www.epa.gov/otaq/regs/fuels/diesel/prfinal.wpd 
(U.S. EPA) U. S. Environmental Protection Agency. (1999a). "Control of Diesel Fuel Quality," Federal Register, Advance Notice of Proposed Rulemaking, 40 CFR Parts 80 and 86, Vol. 64, No. 92, p. 26142, May 13.

(U.S. EPA) U. S. Environmental Protection Agency. (1999b). "Diesel Fuel Quality: Advance Notice of Proposed Rulemaking," Regulatory Announcement, Air and Radiation Office of Mobil Sources, EPA420-F-99-011, May. 


\section{INTERNAL DISTRIBUTION}

1. G.E. Courville

2. T.R. Curlee

3. S. Das

4. Ronald L. Graves

5. D.L. Greene

6-30. G.R. Hadder

31. P.S. $\mathrm{Hu}$
32. R.N. McGill

33. C.I. Moser

34. R.B. Shelton

35. ORNL Patent Office

36. Central Research Library

37. Laboratory Records

38. Laboratory Records--RC

\section{EXTERNAL DISTRIBUTION}

39. L.A. Abron, President, PEER Consultants, P.C., 1460 Gulf Blvd., $11^{\text {th }}$ Floor, Clearwater, Florida 34630

40. Susan L. Cutter, Professor and Chair, Director, Hazards Research Lab, Department of Geography, University of South Carolina, Columbia,, South Carolina 29208

41. S.G. Hildebrand, Director, Environmental Sciences Division, Oak Ridge National Laboratory, Post Office Box 2008, Oak Ridge, Tennessee 37831-6037

42. P.R. Rittelmann, FAIA, Executive Vice President, Burt Hill Kosar Rittelmann Associates, 400 Morgan Center, Butler, Pennsylvania 16001-5977

43. S.F. Tierney, The Economic Resource Group, Inc., One Mifflin Place, Cambridge, Massachusetts 02138

44. C.M. Walton, Ernest H. Cockrell Centennial Chair in Engineering and Chairman, Department of Civil Engineering, University of Texas at Austin,E Cockrell, Jr. Hall I, Suite 4210, Austin, Texas 78712-1075

45-54. OSTI, U.S. Department of Energy, P.O. Box 62, Oak Ridge, Tennessee 37831

55. R.W. Crawford, RW Crawford Energy Systems, 2853 S. Quail Trail, Tucson, AZ 85730-5627

56. R. Cundiff, 1741 Heather Lake Court, Andover, KS 67002

57. P.R. Devlin, EE-32, U.S. Department of Energy, Forrestal Building, 1000 Independence Avenue, S.W., Washington, DC 20585

58. J.A. Garbak, EE-32, U.S. Department of Energy, Forrestal Building, 1000 Independence Avenue, S.W., Washington, DC 20585

59. S.J. Goguen, EE-33, U.S. Department of Energy, Forrestal Building, 1000 Independence Avenue, S.W., Washington, DC 20585 
60. A.M. Hartstein, FE-3, U.S. Department of Energy, Germantown, 19901 Germantown Road, Germantown, MD 20874-1290

61. K.G. Duleep, Energy and Environmental Analysis, Inc., 1655 North Fort Meyer Drive, Arlington, VA 22209

62. H.T. McAdams, AccaMath Services, Carrollton, IL 62016

63-67. B.D. McNutt, PO-62, Room 7H-021, U.S. Department of Energy, Forrestal Building, 1000 Independence Avenue, S.W., Washington, DC 20585

68. P.D. Patterson, Jr., EE-30, U.S. Department of Energy, Forrestal Building, 1000 Independence Avenue, S.W., Washington, DC 20585

69. Richard A. Rykowski, Assessment and Standards Division, U.S. Environmental Protection Agency, 2000 Traverwood Drive, Ann Arbor, MI 48105

70. Gurpreet Singh, EE-33, U.S. Department of Energy, Forrestal Building, 1000 Independence Avenue, S.W., Washington, DC 20585

71. M. Singh, Argonne National Laboratory, 955 L'Enfant Plaza, SW, Suite 6000, Washington, DC 20024-2168 